\title{
Quality of Seeds of Upland Rice Lines Adapted to the State of Minas Gerais, Brazil
}

\author{
Heloisa Oliveira dos Santos, Flávia Barbosa Silva Botelho, \\ Ana Cláudia de Amorim Fonseca, Ricardo Kenji Uenojo, Marcela Pedroso Mendes*, \\ Edila Vilela de Resende Von Pinho \\ Department of Agriculture, Federal University of Lavras, Lavras, Brazil \\ Email: heloisasantos@dag.ufla.br, flaviabotelho@dag.ufla.br, ana.c.amorim@gmail.com, \\ ricardokenji92@gmail.com, ${ }^{*}$ celapmendes@gmail.com, edila@dag.ufla.br
}

Received 3 June 2015; accepted 4 August 2015; published 7 August 2015

Copyright (C) 2015 by authors and Scientific Research Publishing Inc.

This work is licensed under the Creative Commons Attribution International License (CC BY). http://creativecommons.org/licenses/by/4.0/

\section{Open Access}

\begin{abstract}
In the final stages of a plant breeding program, a crucial step is the multiplication of seeds in production fields. Besides a solid planning, the seeds multiplication needs a special attention to guarantee seeds with high quality, genetic integrity, high germination and vigor to the farmer. The aim of this study was to evaluate the physiologic quality, enzymatic expression and respiratory activity of seeds of 20 elite upland rice lines adapted to the state of Minas Gerais, Brazil, from the upland rice breeding program from three Brazilians research institutions. The quality parameters evaluated were root protrusion, number of normal seedlings in the germination test, number of normal seedlings in the germination first count, initial stand from emergence test, speed of emergence index, seedlings shoot and root length, percentage of $\mathrm{O}_{2}$ and $\mathrm{CO}_{2}$ from respiratory activity and the expression pattern of the enzymes alcohol dehydrogenase (ADH) and malate dehydrogenase (MDH). The seeds quality varied among lines, allowing the selection of lines with best performance. The respiratory activity was lower in seeds of lines with high quality. The enzyme ADH was an excellent marker to infer about the quality of seeds, and the variation in the expression of MDH did not depend on the quality of rice seeds. The lines BRS Esmeralda, CMG1896 and CMG1509 showed high physiologic quality in their seeds, and therefore, they should receive higher attention in rice breeding programs.
\end{abstract}

\section{Keywords}

Oriza sativa, Physiologic Quality, Enzymatic Expression, Respiratory Activity, Vigor

\footnotetext{
${ }^{*}$ Corresponding author.

How to cite this paper: dos Santos, H.O., Botelho, F.B.S., de Amorim Fonseca, A.C., Uenojo, R.K., Mendes, M.P. and de Resende Von Pinho, E.V. (2015) Quality of Seeds of Upland Rice Lines Adapted to the State of Minas Gerais, Brazil. American Journal of Plant Sciences, 6, 1920-1927. http://dx.doi.org/10.4236/ajps.2015.612193
} 


\section{Introduction}

Consumed by more than half of the world's population, rice (Oryza sativa L.) is one of the most cultivated crops in the world, and the most important crop in many development countries, playing a strategic role in economic and social politics [1].

The world rice production was nearly 724 millions of tons in 2014 [2]. Brazil is the only non-Asian country that is among the ten biggest producers of rice, producing almost 12,400 millions of tons in 2344 hectares in the 2014/2015 growing season. The main producing state is Rio Grande do Sul, responsible for 66.7\% of the production, followed by Santa Catarina, responsible for 8.7\%, and Maranhão, responsible for 5.4\% [3].

In the $80 \mathrm{~s}$, the upland rice has come to represent $61 \%$ of the planted area in the state of Minas Gerais [3]. However, the low productivity, the absence of adapted genotypes and the competition with irrigated rice from the south of Brazil contributed to the drastic reduction of the area with upland rice in the state of Minas Gerais.

In the last few years, the upland rice breeding program from the research institutions UFLA (Universidade Federal de Lavras), EPAMIG (Empresa de PesquisaAgropecuária de Minas Gerais) and EMBRAPA (EmpresaBrasileira de Pesquisa Agropecuária) developed many genotypes with high genetic performance for grain yield production, drought resistance, short development period, good cooking and industrial grain quality adapted to the state of Minas Gerais, which became self sufficient in rice production. However, similar to what happens in many plant breeding programs, characters related to the seed quality are not commonly evaluated, and the late attention to these characters may generate unnecessary costs to companies.

There are very few studies that discuss physiological and biochemical changes in seeds of rice cultivars, as well as their relation with enzymatic expression and respiratory activity. Therefore, the aim of this study was to evaluate the physiologic quality, enzymatic expression and respiratory activity of seeds of elite upland rice lines adapted to the state of Minas Gerais.

\section{Material and Methods}

Twenty elite inbred lines from the Upland Rice Breeding Program from UFLA, EMBRAPA and EPAMIG were carried out to available the seeds. The field experiment was located in the EPAMIG experimental station in Patos de Minas-MG, Brazil, and a sample of the seeds from each line were sent to the Central Seeds Lab from the Agriculture Department of UFLA to perform the quality tests. The seeds were treated with the commercial fungicide Vitavax-Thiram ${ }^{\circledR}, 0.003 \mathrm{~L}$ by kilogram of seed.

It was performed a germination test (GT) using 50 seeds of each inbred line with four replicates, distributed on Germitest ${ }^{\circledR}$ paper moistened with water amount equivalent to 2.5 times the mass of dry substrate, and maintained in germination chamber at $25^{\circ} \mathrm{C}$ degrees. Two counts of the number of normal seedlings were performed. A germination first count (GFC) was performed at the fifth day after installing the germination test, and the second count was performed at the fourteenth day, according to recommendation in Brasil [4]. A seedling was considered normal when showing $0.5 \mathrm{~cm}$ of shoot length and $2.5 \mathrm{~cm}$ of root length, and the results were expressed as the average percentage of normal seedlings from the four replicates.

The seedling emergence (ET) was evaluated sowing four replicates of 50 seeds from each line in a $1 \mathrm{~m} \times 4 \mathrm{~m}$ plat with the lines arranged randomly, and expressed as the percentage of emerged seedlings at the seventh and tenth days after sowing to evaluate the initial stand. Also, the speed of emergence (SE) was determined according to Carvalho and Viera [5], using the index proposed by Edmond and Drapala [6]:

$$
S E I=\sum \frac{G n}{N n}
$$

where SEI is the speed of emergence index, $G n$ is the number of normal seedlings emerged at the " $\mathrm{n}$ " count, and $\mathrm{Nn}$ is the number of days between sowing and the " $\mathrm{n}$ " count.

Seedling shoot (SL) and root (RL) length were obtained sowing four replicates of ten seeds from each line in Germitest ${ }^{\circledR}$ paper moistened with water in a proportion of $2.5 \mathrm{~mL}$ of water by each gram of paper, and maintained in germination chamber at $25^{\circ} \mathrm{C}$ degrees for 14 days. Shoot and root length were measured only in the lines that showed these structures in at least $50 \%$ of the seedlings.

Respiratory activity (RA) was determined by the percentage of $\mathrm{CO}_{2}$ and $\mathrm{O}_{2}$ released by the seeds. For that, 50 seeds from each line were wrapped in Germitest ${ }^{\circledR}$ paper moistened with water in the same proportion as described earlier, and placed in falcon tubes for 72 hours. A little role was made in the tube cover and sealed with robber to allow the insertion of a needle to measure $\mathrm{CO}_{2}$ and $\mathrm{O}_{2}$ without gas exchange with the environment. 
The "PBI-Dansensor CHECKPOINT $\mathrm{O}_{2} / \mathrm{CO}_{2}$ " apparatus works as an electrochemical reader that absorbs about $15 \mathrm{~mL}$ of the sample atmosphere and measures the percentage of $\mathrm{CO}_{2}$ and $\mathrm{O}_{2}$.

Analyses of variance were performed with the data from each previous test using the statistical software SISVAR [7], and the means compared according to the Scott-Knott approach [8] with 95\% of probability.

The enzymatic activity (EA) of alcohol dehydrogenase (ADH) and malate dehydrogenase (MDH) were obtained using 25 seeds from each line. The seeds sample was first stored at $-86^{\circ} \mathrm{C}$ degrees to stop any enzymatic activity. Then, PVP (Polyvinylpolypyrrolidone) was used together with liquid nitrogen to smash the seeds. For the enzymes extraction, it was used an extraction buffer (TrisHCl $10.2 \mathrm{M} \mathrm{pH} 8+0.1 \%$ of $\beta$-mercaptoetanol) in the proportion of $250 \mu \mathrm{L}$ by $100 \mathrm{mg}$ of seeds. The samples were homogenized in vortex and maintained in fridge during the night. They were centrifuged in $14.000 \mathrm{rpm}$ for 30 minutes in $4^{\circ} \mathrm{C}$ degrees, and $60 \mu \mathrm{L}$ of the sample were added to a polyacrylamide gel ( $7.5 \%$ of separator gel and $4.5 \%$ of concentrator gel) to perform electrophoretic analysis (150 Volts for 5 hours) using the gel/electrode system Tris-glycine $\mathrm{pH} 8.9$. The enzymatic activity was inferred evaluating the bands intensity in a transilluminator.

\section{Results and Discussion}

Highly significant differences $(\mathrm{p} \leq 0.05)$ between rice lines were detected in the analyses of variance for all characters: root protrusion, number of normal seedlings in the germination test (GT), number of normal seedlings in the germination first count (GFC), initial stand from emergence test (ET), speed of emergence index (SEI) and respiratory analysis (RA).

The lines CMG1967 and CMG2173 showed smaller values for root protrusion. These lines also showed less normal seedlings in GT, followed by the lines BRSMG Caçula and CMG1698. As regarding to the GFC, the line CMG2097 showed the smallest value followed by the lines CMG1967, CMG2074, CMG2089 and CMG1987. For this character, the line CMG1967 overcome the line CMG2173, probably because these lines had different flowering periods, what directly influence the seeds vigor (Table 1).

Table 1. Percentage of root protrusion, normal seedlings in the germination test (GT) and of normal seedlings in the germination first count (GFC) of the 20 rice upland inbred lines, and their coefficient of variation (CV).

\begin{tabular}{|c|c|c|c|}
\hline Lines & $\%$ Protrusion $^{1}$ & $\% \mathrm{GFC}^{1}$ & $\% \mathrm{GT}^{1}$ \\
\hline BRSMG CURINGA & $93 \mathrm{a}$ & $66 \mathrm{~b}$ & $92 \mathrm{a}$ \\
\hline CMG1967 & $75 \mathrm{c}$ & $48 \mathrm{c}$ & $76 \mathrm{c}$ \\
\hline BRS ESMERALDA & $95 \mathrm{a}$ & $85 \mathrm{a}$ & $92 \mathrm{a}$ \\
\hline CMG2170 & $88 \mathrm{~b}$ & $72 b$ & $88 \mathrm{a}$ \\
\hline CMG2173 & $81 \mathrm{c}$ & $69 \mathrm{~b}$ & $77 \mathrm{c}$ \\
\hline BRSMG CAÇULA & $84 \mathrm{~b}$ & $71 \mathrm{~b}$ & $84 \mathrm{~b}$ \\
\hline CMG1097-7 & $94 \mathrm{a}$ & $68 \mathrm{~b}$ & $96 \mathrm{a}$ \\
\hline CMG2074 & $89 \mathrm{~b}$ & $59 \mathrm{c}$ & $92 \mathrm{a}$ \\
\hline CMG1698 & $86 \mathrm{~b}$ & $72 b$ & $82 \mathrm{~b}$ \\
\hline CMG2085 & $94 \mathrm{a}$ & $68 \mathrm{~b}$ & $90 \mathrm{a}$ \\
\hline BRSMG CARAVERA & $96 \mathrm{a}$ & $79 \mathrm{a}$ & $96 \mathrm{a}$ \\
\hline BRSMG RELÂMPAGO & $95 \mathrm{a}$ & $91 \mathrm{a}$ & $95 \mathrm{a}$ \\
\hline CMG1511 & $89 \mathrm{~b}$ & $83 \mathrm{a}$ & $89 \mathrm{a}$ \\
\hline CMG2089 & $88 \mathrm{~b}$ & $54 \mathrm{c}$ & $90 \mathrm{a}$ \\
\hline CMG1896 & $96 \mathrm{a}$ & $79 \mathrm{a}$ & $90 \mathrm{a}$ \\
\hline CMG2097 & $85 \mathrm{~b}$ & $34 \mathrm{~d}$ & $89 \mathrm{a}$ \\
\hline CMG2017 & $93 \mathrm{a}$ & $79 \mathrm{a}$ & $91 \mathrm{a}$ \\
\hline CMG1977 & $92 \mathrm{a}$ & $75 \mathrm{~b}$ & $91 \mathrm{a}$ \\
\hline CMG1509 & $98 \mathrm{a}$ & $88 \mathrm{a}$ & $95 \mathrm{a}$ \\
\hline CMG1987 & $96 \mathrm{a}$ & $49 \mathrm{c}$ & $94 \mathrm{a}$ \\
\hline CV (\%) & 5,09 & 12,46 & 5,27 \\
\hline
\end{tabular}

${ }^{1}$ Means followed by the same letters at line do not differ by Scott-Knott test with a probability of $95 \%$. 
Considering the tests simulating field conditions, the lines BRSMG Curinga and CMG2173 showed the smaller initial stand, while the lines BRS Esmeralda, CMG2089, CMG1896 and CMG1509 showed the highest values, being considered superior than the other lines. For the emergence test in plat, the lines BRSMG Curinga, CMG1967, CMG2170, CMG2173 and BRSMG Caçula had the worse performance. Finally, considering the speed of emergence, the lines that had the smallest SEI were CMG1967, CMG2173 and BRSMG Caçula (Table 2).

Taking into account all characterspreviously discussed simultaneously, the lines that had the best performance were BRS Esmeralda, CMG1896 and CMG1509, and the line that had the worse performance was CMG1967. Differences in the number of normal seedlings in germination, root protrusion, SEI and number of seedlings in emergence were observed between genotypes of irrigated rice [9], conventional and transgenic genotypes of soybeans [10], upland rice cultivars [11], maize genotypes [12], common bean genotypes [13] and hybrids of pepper [14].

The results of the evaluation of the characters related to the seedlings development are presented in Table 3 . For shoot length, the lines BRSMG Curinga, CMG2089, CMG1896 showed the highest values, and the lines BRSMG Caravera, BRSMG Relâmpago, CMG1511 and CMG1987 showed intermediate values. The line CMG1967 had the smallest value, considered as having a bad performance.

For root length, the lines that showed the smallest values were CMG1967, BRS Esmeralda and CMG2170,

Table 2. Percentage of normal seedlings at the initial stand, emergence in plat and speed of emergence index (SEI) of the 20 upland rice lines, and their coefficient of variation (CV).

\begin{tabular}{cccc}
\hline Lines & \% Initial Stand & \% Emergency $^{1}$ & \% SEI \\
\hline BRSMG CURINGA & $6 \mathrm{~d}$ & $89 \mathrm{~b}$ & $3.00 \mathrm{a}$ \\
CMG1967 & $15 \mathrm{c}$ & $75 \mathrm{~b}$ & $2.25 \mathrm{~b}$ \\
BRS ESMERALDA & $75 \mathrm{a}$ & $91 \mathrm{a}$ & $3.25 \mathrm{a}$ \\
CMG2170 & $64 \mathrm{~b}$ & $82 \mathrm{~b}$ & $2.75 \mathrm{a}$ \\
CMG2173 & $6 \mathrm{~d}$ & $84 \mathrm{~b}$ & $2.50 \mathrm{~b}$ \\
BRSMG CAÇULA & $17 \mathrm{c}$ & $82 \mathrm{~b}$ & $2.00 \mathrm{~b}$ \\
CMG1097-7 & $18 \mathrm{c}$ & $92 \mathrm{a}$ & $3.00 \mathrm{a}$ \\
CMG2074 & $14 \mathrm{c}$ & $97 \mathrm{a}$ & $3.00 \mathrm{a}$ \\
CMG1698 & $17 \mathrm{c}$ & $93 \mathrm{a}$ & $3.00 \mathrm{a}$ \\
CMG2085 & $48 \mathrm{~b}$ & $98 \mathrm{a}$ & $3.25 \mathrm{a}$ \\
BRSMG CARAVERA & $23 \mathrm{c}$ & $93 \mathrm{a}$ & $3.00 \mathrm{a}$ \\
BRSMG RELÂMPAGO & $21 \mathrm{c}$ & $95 \mathrm{a}$ & $3.00 \mathrm{a}$ \\
CMG1511 & $26 \mathrm{c}$ & $90 \mathrm{a}$ & $2.75 \mathrm{a}$ \\
CMG2089 & $77 \mathrm{a}$ & $95 \mathrm{a}$ & $3.00 \mathrm{a}$ \\
CMG1896 & $77 \mathrm{a}$ & $92 \mathrm{a}$ & $3.00 \mathrm{a}$ \\
CMG2097 & $59 \mathrm{~b}$ & $93 \mathrm{a}$ & $2.75 \mathrm{a}$ \\
CMG2017 & $58 \mathrm{~b}$ & $96 \mathrm{a}$ & $3.25 \mathrm{a}$ \\
CMG1977 & $54 \mathrm{~b}$ & $91 \mathrm{a}$ & $3.00 \mathrm{a}$ \\
CMG1509 & $74 \mathrm{a}$ & $97 \mathrm{a}$ & $3.00 \mathrm{a}$ \\
CMG1987 & $60 \mathrm{~b}$ & $91 \mathrm{a}$ & $2.75 \mathrm{a}$ \\
CV (\%) & 20.71 & 7.27 & 11.61 \\
\hline
\end{tabular}

\footnotetext{
${ }^{1}$ Means followed by the same letters at line do not differ by Scott-Knott test with a probability of $5 \%$.
} 
Table 3. Shoot length and root length of the 20 upland rice lines, and their coefficient of variation (CV).

\begin{tabular}{|c|c|c|}
\hline Lines & Shoot Length $(\mathrm{cm})^{1}$ & Root Length $(\mathrm{cm})^{1}$ \\
\hline BRSMG CURINGA & $1.73 \mathrm{a}$ & $2.53 \mathrm{~d}$ \\
\hline CMG 1967 & $2.26 \mathrm{~d}$ & $1.42 \mathrm{e}$ \\
\hline BRS ESMERALDA & $3.14 \mathrm{c}$ & $1.96 \mathrm{e}$ \\
\hline CMG 2170 & $4.08 \mathrm{c}$ & $1.38 \mathrm{e}$ \\
\hline CMG 2173 & $3.01 \mathrm{c}$ & $2.35 \mathrm{~d}$ \\
\hline BRSMG CAÇULA & $3.28 \mathrm{c}$ & $4.04 \mathrm{c}$ \\
\hline CMG 1097-7 & $4.11 \mathrm{c}$ & $3.33 \mathrm{c}$ \\
\hline CMG 2074 & $3.83 \mathrm{c}$ & $4.55 \mathrm{c}$ \\
\hline CMG 1698 & $3.53 \mathrm{c}$ & $4.18 \mathrm{c}$ \\
\hline CMG 2085 & $4.71 \mathrm{c}$ & $4.70 \mathrm{c}$ \\
\hline BRSMG CARAVERA & $5.31 \mathrm{~b}$ & $6.32 \mathrm{~b}$ \\
\hline BRSMG RELÂMPAGO & $5.03 \mathrm{~b}$ & $6.60 \mathrm{~b}$ \\
\hline CMG 1511 & $5.45 \mathrm{~b}$ & $6.04 \mathrm{~b}$ \\
\hline CMG 2089 & $6.23 \mathrm{a}$ & $4.30 \mathrm{c}$ \\
\hline CMG 1896 & $6.44 \mathrm{a}$ & $7.82 \mathrm{a}$ \\
\hline CMG 2097 & $4.57 \mathrm{c}$ & $3.34 \mathrm{c}$ \\
\hline CMG 2017 & $3.95 \mathrm{c}$ & $3.91 \mathrm{c}$ \\
\hline CMG 1977 & $5.33 \mathrm{~b}$ & $4.30 \mathrm{c}$ \\
\hline CMG 1509 & $4.60 \mathrm{c}$ & $4.46 \mathrm{c}$ \\
\hline CMG 1987 & $3.32 \mathrm{c}$ & $2.97 \mathrm{~d}$ \\
\hline $\mathrm{CV}(\%)$ & 2.32 & 1.94 \\
\hline
\end{tabular}

${ }^{1}$ Means followed by the same letters at line do not differ by Scott-Knott test with a probability of $5 \%$.

followed by the lines BRSMG Curinga, CMG2173 and CMG1987. The bad result of the line CMG1967 agrees with the results showed in Table 2, suggesting that the seeds from this line have poor physiologic quality. The line CMG1896 showed the highest root length (Table 3).

The variability of seeds physiologic quality and its direct relation with the seedling development were also reported in common bean [15], black oat [16] and popcorn maize genotypes [17], agreeing with the results found in this study.

The results of the respiratory analyses are presented in Table 4. The lines BRS Esmeralda, CMG1896 and CMG1509 had the best performance, since they showed high percentage of $\mathrm{O}_{2}$ and low percentage of $\mathrm{CO}_{2}$. The line CMG1967, on the other hand, showed low $\mathrm{O}_{2}$ and high $\mathrm{CO}_{2}$, showing the worse performance of all lines (Table 4).

The respiratory system is a biological process which reduced organic composts are mobilized and subsequently oxidized. The photosynthetic process uses $\mathrm{CO}_{2}$ and releases $\mathrm{O}_{2}$, wherein higher $\mathrm{O}_{2}$ releasing rates are related to genotypes that uses aerobic routes that produce fewer quantities of free radicals. The seeds of those genotypes deteriorate less and, consequently, have higher values for germination and vigor.

Using the tests of Pettenkofer and of Titration to measure the respiratory rate in seeds of different maize genotypes, Correa [18] observed that the more vigor the seeds have, more oxygen is released, so these characters have a high and positive correlation. Similar results were found in seeds of cotton [19], common bean [15] and pepper hybrids [14]. 
Table 4. Percentage of $\mathrm{O}_{2}$ and $\mathrm{CO}_{2}$ obtained by the respiratory activity analyses of the 20 upland rice lines, and their coefficient of variation $(\mathrm{CV})$.

\begin{tabular}{|c|c|c|}
\hline Lines & $\mathrm{O}_{2}(\%)^{1}$ & $\mathrm{CO}_{2}(\%)^{1}$ \\
\hline BRSMG CURINGA & $22.1 \mathrm{~b}$ & $1.3 \mathrm{~b}$ \\
\hline CMG 1967 & $11.7 \mathrm{e}$ & $2.1 \mathrm{~d}$ \\
\hline BRS ESMERALDA & $23.3 \mathrm{a}$ & $0.5 \mathrm{a}$ \\
\hline CMG 2170 & $20.3 \mathrm{~b}$ & $0.4 \mathrm{a}$ \\
\hline CMG 2173 & $22.2 \mathrm{~b}$ & $0.8 \mathrm{a}$ \\
\hline BRSMG CAÇULA & $18.5 \mathrm{~d}$ & $0.7 \mathrm{a}$ \\
\hline CMG 1097-7 & $18.6 \mathrm{~d}$ & $1.3 \mathrm{~b}$ \\
\hline CMG 2074 & $18.1 \mathrm{~d}$ & $1.8 \mathrm{c}$ \\
\hline CMG 1698 & $17.3 \mathrm{~d}$ & $0.5 \mathrm{a}$ \\
\hline CMG 2085 & $18.5 \mathrm{~d}$ & $1.4 \mathrm{~b}$ \\
\hline BRSMG CARAVERA & $23.1 \mathrm{a}$ & $1.7 \mathrm{c}$ \\
\hline BRSMG RELÂMPAGO & $18.5 \mathrm{~d}$ & $1.7 \mathrm{c}$ \\
\hline CMG 1511 & $21.2 \mathrm{~b}$ & $1.6 \mathrm{c}$ \\
\hline CMG 2089 & $22.8 \mathrm{~b}$ & $1.0 \mathrm{~b}$ \\
\hline CMG 1896 & $23.8 \mathrm{a}$ & $0.6 \mathrm{a}$ \\
\hline CMG 2097 & $17.5 \mathrm{~d}$ & $1.3 \mathrm{~b}$ \\
\hline CMG 2017 & $21.8 \mathrm{~b}$ & $0.4 \mathrm{a}$ \\
\hline CMG 1977 & $19.6 \mathrm{c}$ & $0.6 \mathrm{a}$ \\
\hline CMG 1509 & $24.7 \mathrm{a}$ & $0.5 \mathrm{a}$ \\
\hline CMG 1987 & $13.7 \mathrm{e}$ & $1.8 \mathrm{c}$ \\
\hline CV (\%) & 1.03 & 1.32 \\
\hline
\end{tabular}

${ }^{1}$ Means followed by the same letters at line do not differ by Scott-Knott test with a probability of $5 \%$.

The enzymatic activity for the enzyme alcohol dehydrogenase (ADH) can be observed in Figure 1. Analyzing the intensity of the bands, it was possible to infer that the line CMG1896 (line15) had a low expression for this enzyme. It is important to notice that the line CMG1896 showed the best performance in the quality tests and the lowest rate of $\mathrm{CO}_{2}$ released, being characterized by the one with the best seed quality compared with the 19 others. The same happened to the line CMG1509 (line 19) that showed a great performance in the germination and vigor tests as well as higher $\mathrm{O}_{2}$ release.

Electrophoretic patterns of enzymes related to the respiratory process are excellent markers to infer about the quality of seeds. The enzyme ADH acts in the anaerobic metabolism wherein the acetaldehyde is reduced in ethanol [20]. The final products of this metabolism are toxic to cells, but the ethanol fermentative metabolism seems to be less deleterious compared to acetaldehyde [21]. Therefore, the occurrence of ADH activity suggests the presence of acetaldehyde instead of ethanol, leading to seeds with poor quality.

Similar results were found by Brandão Junior [22] in maize seeds. He observed most intensity of ADH bands when increasing aging time, when the quality of the seeds is lower. According to Torggler et al. [23], the ADH enzyme has two important linked locus in maize, Adh1 and Adh2, which are frequently studied in the aspect of gene expression regulation because they have a well defined function under anaerobic conditions.

It was possible to detect expression to the enzyme malate dehydrogenase (MDH) in all lines studied (Figure 2). A subtle major activity happened in lines that showed high physiologic quality, as the lines BRS Esmeralda 


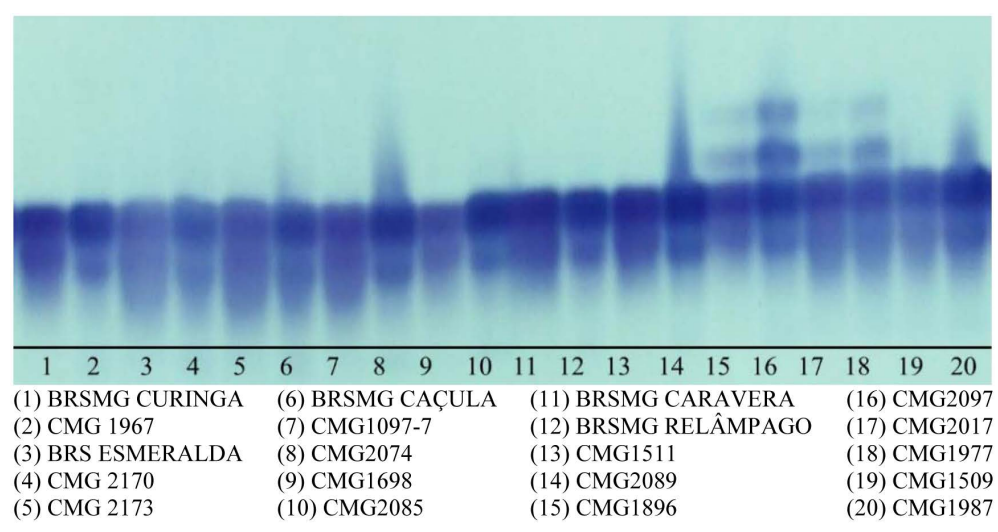

Figure 1. Expression pattern of the enzyme alcohol dehydrogenase (ADH) in seeds of the 20 upland rice lines.

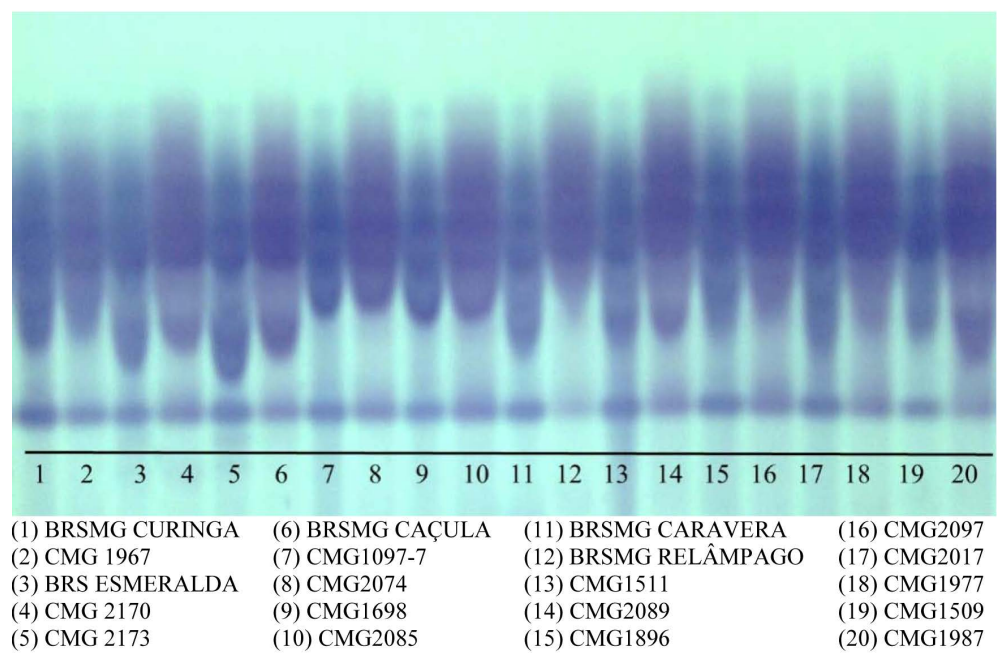

Figure 2. Expression pattern of the enzyme malate dehydrogenase (MDH) in seeds of the 20 upland rice lines.

(line 3), CMG2017 (line 17) and CMG1509 (line 19). However, MDH expression showed little variation between lines, probably because this enzyme can be found in multiple organelles in plants.

Similarly, Brandão Junior [22] did not found correlation between MDH activity and seeds physiologic quality in maize. Satters et al. [24] verified that increasing aging time in soybean less influenced MDH activity. Therefore, MDH activity was not a good marker to infer about seeds quality.

\section{Conclusions}

The enzyme alcohol dehydrogenase (ADH) was an excellent marker to infer about the quality of seeds. The variation in the expression of malate dehydrogenase (MDH) did not depend on the quality of rice seeds.

The lines BRS Esmeralda, CMG1896 and CMG1509 showed high physiologic quality in their seeds, and therefore they should receive higher attention in Upland Rice Breeding Programs.

\section{References}

[1] Walter, M. and Avila, L.A. (2008) Arroz: Composição e característicasnutricionais. Ciência Rural, 38, 1184-1192. http://dx.doi.org/10.1590/S0103-84782008000400049

[2] FAO_Food and Agriculture Organization of the United Nations http://www.fao.org

[3] CONAB - CampanhaNacional de Abastecimento http://www.conab.gov.br 
[4] Brasil (2009) Ministério da Agricultura, Pecuária e Abastecimento. Regras para análise de sementes, Brasília.

[5] Carvalho, N.M. and Vieira, R.D. (1994) Testes de vigor em sementes. FUNEP, Jaboticabal.

[6] Edmond, J.B. and Drapala, W.J. (1958) The Effects of Temperature, Sand and Soil, and Acetone on Germination of Okra Seed. Proceedings of the American Society Horticutural Science, Alexandria, 71, 428-434.

[7] Ferreira, D.F. (2011) Sisvar: A Computer Statistical Analysis System. Ciência e Agrotecnologia, 35, 1039-1042.

[8] Scott, A. and Knott, M. (1974) Cluster-Analysis Method for Grouping Means in Analysis of Variance. Biometrics, 30, 507-512. http://dx.doi.org/10.2307/2529204

[9] Hofs, A., Schuch, L.O.B., Peske, S.T. and Barros, A.C.S.A. (2004) Emergência e crescimento de plântulas de arroz em resposta á qualidade fisiológica de sementes. Revista Brasileira de Sementes, 26, 1, 92-97. http://dx.doi.org/10.1590/s0101-31222004000100014

[10] Carvalho, T.C., Grzybowski, C.R.S., Ohlson, O.C. and Panobianco, M.(2012) Comparação da qualidade fisiológica de sementes de soja convencional e de sua derivada transgênica. Revista Brasileira de Sementes, 34, 164-170. http://dx.doi.org/10.1590/S0101-31222012000100020

[11] Souza, L.C.D. (2005) Qualidade fisiológica de sementes de arroz da região de Matupá-MT. Revista Ciências Agro Ambientais, 3, 110-116.

[12] Hamawaki, O.T., Juliatti, F.C., Gomes, G.M. and Rodrigues, F.A. (2002) Avaliação da qualidade fisiológica e sanitária de sementes de genótipos de soja do ciclo precoce/médio. Fitopatologia Brasileira, 27, 201-205. http://dx.doi.org/10.1590/S0100-41582002000200013

[13] Kikuti, H., Andrade, M.J.B., Kikute, A.L.P. and Pereira, C.E. (2006) Qualidade de sementes de genótipos de feijão em função da adubação. Revista Ciência Agronômica, 37, 37-43.

[14] Pereira, E.M. (2012) Avaliação da qualidade fisiológica de sementes de pimenta e pimentão por meio da atividade respiratória. Dissertação (Mestrado em Fitotecnia), Universidade Federal de Lavras.

[15] Aumonde, T.Z., Marini, P., Moraes, D.M., Maia, M.S., Pedó, T., Tilmann, M.A.A. and Villela, F.A. (2012) Classificação do vigor de sementes de feijão-miúdopelaatividaderespiratória. Interciência, 37, 55-58.

[16] Schuch, L.O.B., Nedel, J.L., Assis, F.N. and Maia, M.S. (1999) Crescimento em laboratório de plântulas de AveiaPreta em função do vigor de sementes. Revista Brasileira de Sementes, 21, 229-234. http://dx.doi.org/10.17801/0101-3122/rbs.v21n1p229-234

[17] Moterle, L.M., Lopes, P.C., Braccini, A.L. and Scapim, C.A. (2006) Germinação de sementes e crescimento de plântulas de cultivares de milho-pipoca submetidas ao estresse hídrico salino. Revista Brasileira de Sementes, 28, 169-176. http://dx.doi.org/10.1590/S0101-31222006000300024

[18] Correa, P.D. (2014) Avaliação da qualidade fisiológica de sementes de milho por meio da atividade respiratória. Monografia (Graduação em Agronomia),Universidade Federal de Lavras.

[19] Venske, E., Abreu Jr., J.S., Sousa, A.M., Martins, L.F. and Moraes, D.M. (2014) Atividade respiratória como teste de vigor em sementes de algodão. Revista Brasileira de Ciências Agrárias, 9, 174-179. http://dx.doi.org/10.5039/agraria.v9i2a3518

[20] Buchanan, B.B., Gruissem, W. and Jones, R.L. (2000) Biochemistry and Molecular Biology of Plants. Rockville.

[21] Zhang, M., Maeda, Y., Futihata, Y., Noramura, Y.I. and Esashi, Y. (1994) A Mechanism of Seed Deterioration in Relation to Volatile Compounds Evoked by Dry Seeds Themselves. Seed Science Research, 4, 49-56. http://dx.doi.org/10.1017/S0960258500001999

[22] Brandão Jr., D.E. (1996) Eletroforese de proteína e isoenzimanaavaliação da qualidade de sementes de milho. Dissertação (Mestradoem Fitotecnia), Universidade Federal de Lavras.

[23] Torggler, M.G.F., Contel, E.P.B. and Torggler, S.P. (1995) Isoenzimas: Variabilidade genetic em plantas. Ribeirão Preto.

[24] Satters, J.R., Abdel-Ghany, A., Elbagoury, O. and West, S.H. (1994) Soybean Seed Deterioration and Response to Priming: Changes in Specific Enzyme Activities in Extracts from Dry and Germinating Seeds. Seed Science, 4, 33-41. 